\title{
Artemisone effective against murine cerebral malaria
}

\author{
Judith H Waknine-Grinberg ${ }^{1,2}$, Nicholas Hunt ${ }^{3}$, Annael Bentura-Marciano ${ }^{1}$, James A McQuillan ${ }^{3}$, Ho-Wai Chan",
} Wing-Chi Chan ${ }^{4}$, Yechezkel Barenholz ${ }^{2}$, Richard K Haynes ${ }^{4}$, Jacob Golenser ${ }^{1,3^{*}}$

\begin{abstract}
Background: Artemisinins are the newest class of drug approved for malaria treatment. Due to their unique mechanism of action, rapid effect on Plasmodium, and high efficacy in vivo, artemisinins have become essential components of malaria treatment. Administration of artemisinin derivatives in combination with other antiplasmodials has become the first-line treatment for uncomplicated falciparum malaria. However, their efficiency in cases of cerebral malaria (CM) remains to be determined.

Methods: The efficacy of several artemisinin derivatives for treatment of experimental CM was evaluated in ICR or C57BL/6 mice infected by Plasmodium berghei ANKA. Both mouse strains serve as murine models for CM.

Results: Artemisone was the most efficient drug tested, and could prevent death even when administered at relatively late stages of cerebral pathogenesis. No parasite resistance to artemisone was detected in recrudescence. Co-administration of artemisone together with chloroquine was more effective than monotherapy with either drug, and led to complete cure. Artemiside was even more effective than artemisone, but this substance has yet to be submitted to preclinical toxicological evaluation.
\end{abstract}

Conclusions: Altogether, the results support the use of artemisone for combined therapy of CM.

\section{Background}

The most critical problem currently limiting malaria treatment is the emergence and spread of parasite resistance to the majority of anti-malarial drugs in use [1]. Improper or incomplete monotherapy of malaria has caused the development of resistance to the commonly used chloroquine [2,3] and mefloquine [4], and even to quinine, which has been a mainstay in the anti-malarial pharmacopeia for approximately two centuries [5]. Artemisinin derivatives comprise the most recently developed class of anti-malarial drugs currently approved for human use. These derivatives (Figure 1) include artesunate and artemether, their metabolite dihydroartemisinin (DHA), and artemisone [6,7]. All artemisinins comprise a peroxide bridge, essential for activity, embedded within the 1,2,4-trioxane unit in a fused tetracyclic sesquiterpene scaffold.

\footnotetext{
* Correspondence: golenser@md.huji.ac.il

'Department of Microbiology and Molecular Genetics, The Hebrew

University of Jerusalem, Jerusalem, 91120, Israel Full list of author information is available at the end of the article
}

Artemisinin-type drugs have been proposed to act via several mechanisms. A widely held view is that ferrous iron, either 'free' or in haemoglobin $(\mathrm{Hb})$, or its breakdown product, haem, is required for activation of the peroxide [8-11]. Fenton chemistry involving reductive cleavage of the peroxide by $\mathrm{Fe}(\mathrm{II})$ is considered to lead to $\mathrm{C}$-centered radicals that are the presumed cytotoxic agents [12]. For haem, it is assumed that the C-radicals alkylate the haem nucleus to provide adducts that discharge the potent activities of the parent artemisinin $[13,14]$. However, artemisinins susceptible to decomposition by haem-Fe(II) display enhanced activities against parasites cultured under carbon monoxide (CO), an agent that passivates haem-Fe(II) by formation of stable haem- $\mathrm{Fe}(\mathrm{II})-\mathrm{CO}$ complexes; this thereby discounts haeme as an activator of artemisinins $[15,16]$. Artemisinins are known mediators of oxidative stress [17] that enhance oxidative stress in malaria parasites $[18,19]$. Oxidative damage has been observed to occur in various parasite membranes [6], the mitochondria [20] and DNA [21]. Another view, based on the observation that in vitro anti-malarial activity is sensitive to steric effects,
C Biomed Central 


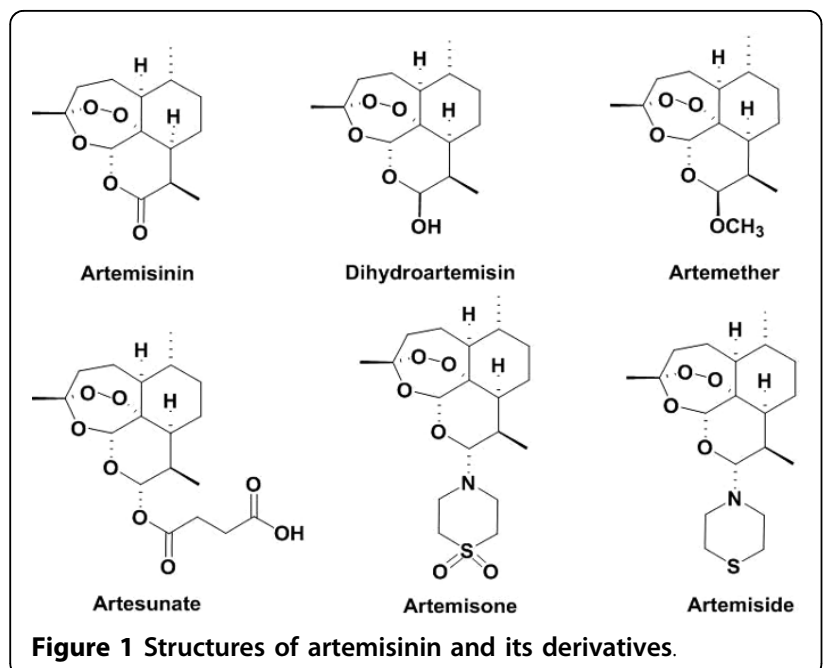

suggests that the molecule undergoes activation after binding to a specific protein target site. Artemisinins have been shown to interfere with the activity of the Plasmodium falciparum sarcoplasmic/endoplasmic calcium ATPase (SERCA), PfATP6 [22]. SERCA is responsible for the maintenance of calcium ion concentrations, which is important for the generation of calciummediated signalling as well as for the correct folding and post-translational processing of proteins. Artemisinins also inhibit endocytosis by the parasite. Although no direct link has been reported, changes in cytosolic $\mathrm{Ca}^{+2}$ levels as a result of SERCA inhibition may have a significant regulatory effect on endocytosis [23].

The question of plasmodial resistance to artemisinins has been a matter of debate [6]. However, there is growing evidence that uncontrolled (non-regulated) use of these drugs is followed by reduced susceptibility and resistance [24-26]. An increase in parasite cytochrome P450 and MDR1 activities may also be the cause of reduced drug efficacy [27]. Artemisinin-based combination therapy (ACT) is recommended for more efficient treatment and for prevention of the induction of drug resistance [28-32]. A recent review [31] describes improved results when ACT is used, compared to nonartemisinin-based combinations. Most of the studies described were performed using artesunate and were directed against uncomplicated falciparum malaria.

The search for new anti-malarial therapeutics has been directed towards identification of new drug targets in the parasite. As many aspects of the disease and its complications are caused by the host anti-malarial immune response, this approach is incomplete. Cerebral malaria $(\mathrm{CM})$, one of the most serious complications of $P$. falciparum infection, affects mainly children and nonimmune adults [33]. In areas of high transmission young children are more affected by severe malaria, including
$\mathrm{CM}$, as immunity is achieved only after a prolonged period of exposure, while in low transmission areas $\mathrm{CM}$ is expressed in older children. The pathogenesis of $\mathrm{CM}$ remains unclear. One explanation is adherence and sequestration of parasitized erythrocytes, peripheral blood mononuclear cells (PBMC) and platelets to vascular endothelial cells lining the small blood vessels of the brain [34]. However, there is no direct proof in humans for a causative relationship between sequestrations of PBMC and the pathogenesis of CM. Studies using a murine model of experimental cerebral malaria (ECM) with Plasmodium berghei ANKA indicate that ECM is a $\mathrm{T}$ cell-mediated disease. In particular, $\mathrm{CD} 8^{+}$cytotoxic $\mathrm{T}$ cells are involved in the destruction of the blood-brain barrier (BBB) by perforin-dependent processes [35-38]. Overall, parasite-triggered cerebral inflammation is considered to be a possible cause of death from CM $[39,40]$. The harmful, dysregulated immune response leading to CM or ECM is mainly of the Th1 type, with overproduction of some cytokines, such as IFN $\gamma$ (initially produced by Th1 cells, and at a later stage also by $\mathrm{CD} 8^{+}$ cytotoxic $\mathrm{T}$ cells), combined with underproduction of others (e.g. IL-10) [41]. Both sequestration and inflammation are needed for induction of cerebral pathogenesis [40]. A preventive measure that will eliminate or reduce even a single factor associated with the cascade of events leading to (E)CM may completely avert it $[6,42]$. In addition to their anti-plasmodial activity, artemisinins have been shown to reduce $\mathrm{CD} 4^{+}$and $\mathrm{CD} 8^{+}$ $\mathrm{T}$ cell inflammatory responses [43-46]. The severity of malarial infection is correlated with both brain endothelial cell activation and blood brain barrier disruption $[47,48]$. Vascular endothelial growth factor (VEGF) activation of vascular and endothelial cells causes disruption of BBB function as well as angiogenesis in blood vessels where parasite sequestration has occurred. This results in haemorrhages and fatal brain oedema, and is thought to be the source of the neurological impairments seen in those that survive the infection [49,50]. Artemisinins have been shown to down-regulate VEGF functions [51,52]; VEGF down-regulation may alleviate the symptoms of $\mathrm{CM}$ and reduce the neurological damage in those who survive the disease [6].

It is apparent that artemisinins, including artemisone, will be useful for the treatment of CM. Artemisone is non-neurotoxic, possesses anti-malarial activities greater than those of artesunate, remains active in the presence of $\mathrm{Hb}-\mathrm{Fe}(\mathrm{II})$, does not alkylate haem-Fe(II) under biologically plausible conditions, and is unaffected by free $\mathrm{Fe}$ (II). In $\mathrm{CM}$, where abnormal quantities of $\mathrm{Hb}-\mathrm{Fe}(\mathrm{II})$, haem-Fe(II), or free $\mathrm{Fe}(\mathrm{II})$ are present [53], artemisone will be less prone to competitive degradation.

Thus, it is clear that the suitability of artemisinin-type drugs for CM prophylaxis and/or therapy merits close 
examination. Our research demonstrates the effects of several artemisinin derivatives on the progression of murine malaria, with an emphasis on artemisone therapy for ECM. The possible induction of artemisone resistance and the efficiency of artemisone monotherapy vs. combined artemisone-chloroquine treatment is also examined.

\section{Methods}

Mice

ICR Harlan-Sprague-Dawley (ICR) or C57Bl/6 Ola-Hsd male mice (C57 Bl/6, from Harlan, Israel; $\mathrm{C} 57 \mathrm{Bl} / 6 \mathrm{Aus}$ from the Animal Resource Centre, Australia:) aged 7-8 weeks were used in all experiments, 6 to 10 mice per group (as described). The mice were housed under standard light and temperature conditions and provided with unlimited access to water and food. All experiments were carried out in accordance with institutional guidelines for animal care, by protocols approved by the Animal Ethical Care Committee of The Hebrew University of Jerusalem or the University of Sydney. Parasitaemia was monitored every other day, from the time of inoculation until death or sacrifice, by thin blood smears prepared from tail blood. These were stained with a $25 \%$ Giemsa solution, examined under a light microscope, and parasitaemia determined as the number of infected red blood cells per 10,000 erythrocytes. Clinical signs of cerebral malaria were evaluated and used for scoring disease severity (Table 1).

\section{Parasites}

Plasmodium berghei ANKA (PbA MRA-311, CDC Atlanta) was maintained in vivo by serial transfer of

Table 1 Scoring chart for definition and severity of ECM disease as per clinical signs

\begin{tabular}{lll}
\hline Appearance & Normal & 0 \\
& Coat ruffled & 1 \\
& Coat staring; panting & 2 \\
\hline Behaviour (undisturbed) & Normal & 0 \\
& Hunched; wobbly gait & 1 \\
& Partial paralysis; immobile* ${ }^{\dagger}$ & 2 \\
& Convulsions; coma* & 3 \\
\hline Food intake & Normal & 0 \\
& Up to $10 \%$ loss in body weight & 1 \\
& $10 \%-15 \%^{*}$ loss in body weight & 2 \\
& More than $15 \%$ loss in body weight & 3 \\
\hline Body temperature & Normal $\left(36-37^{\circ} \mathrm{C}\right)$ & 0 \\
& $34-35^{\circ} \mathrm{C}$ & 1 \\
& $32-33^{\circ} \mathrm{C}^{*}$ & 2 \\
& Below $32^{\circ} \mathrm{C}^{*}$ & 3
\end{tabular}

Mice with a cumulative score of 5 or above are sacrificed, and death deemed to be on the following day.

*Endpoint for mouse sacrifice.

${ }^{\dagger}$ Also in response to stimulation. parasitized erythrocytes (PE) from infected to naïve mice. Experimental mice were infected by intraperitoneal (i.p.) injection of $5 \times 10^{4} \mathrm{PE}$ from peripheral blood of infected donor mice, an inoculum which caused fatal ECM in at least $50 \%$ of infected ICR HSD mice, and $90 \%$ of infected $\mathrm{C} 57 \mathrm{Bl} / 6$ Ola-Hsd mice. A significant increase in the inoculum level reduced the incidence of ECM [54].

In experiments performed at the University of Sydney, P. berghei ANKA (designated PbAus in the text; courtesy of Prof. G. Grau, University of Sydney, Australia), was injected to $\mathrm{C} 57 \mathrm{Bl} / 6 \mathrm{Aus}$ mice at an inoculum of $10^{6}$ $\mathrm{PE}$. Inoculation of $\mathrm{C} 57 \mathrm{Bl} / 6$ mice with PbAus is a well described model, in which the rate of fatal ECM is at least 90\% [55].

The link between death and ECM in mouse models has previously been demonstrated $[41,56]$. Observed clinical symptoms, including an accelerated drop in core body temperature and death at low parasitaemias, indicate ECM $[48,57,58]$. Scoring of disease severity was performed in order to track the development of ECM, according to the severity levels described in Table 1. Infected mice were evaluated for parasitaemia levels, the appearance of neurological symptoms and changes in weight and temperature. Clinical signs of neuropathology that appear 1-2 days before death from ECM include marked coat staring, hunching, wobbly gait and reduced locomotion, convulsions, and coma. Mice that died at a parasitaemia of $15 \%$ or below with accompanying neurological symptoms and drastic reductions in body weight and temperature were considered to have died of ECM. ECM death generally occurred on days 810 post-inoculation. Brain pathology observed in mice dying of ECM includes haemorrhages, mononuculear cell accumulation in small vessels and the development of brain oedema. Untreated mice which did not die from ECM went on to die with severe anaemia and hyperparasitaemia, as has been reported in all other cases where mice are resistant to $P$. berghei ANKAinduced ECM [59].

\section{Drugs}

DHA and artesunate were purchased from the Kunming Pharmaceutical Corporation via the Hong Kong University of Science and Technology, and used as received. Artemisone and artemiside were synthesized from DHA and purified by flash column chromatography, followed by recrystallization according to the procedure previously reported [7]. Dimethyl sulfoxide (DMSO) and chloroquine diphosphate were purchased from SigmaAldrich, Ltd (Israel). All artemisinin derivatives were prepared in DMSO according to the required dosage and administered in a volume of 20-50 $\mu$ l by intraperitoneal injection. Chloroquine diphosphate was dissolved in 
PBS and administered in a $50 \mu \mathrm{l}$ volume by intraperitoneal injection.

\section{Histology}

Mice were deeply anaesthetized and sacrificed by terminal intracardial perfusion with $10 \mathrm{ml}$ ice-cold PBS. Organs were removed and fixed overnight in 10\% (v/v) neutral buffered formalin (Fronine, Australia). Paraffinembedded tissues were cut into 5-7 $\mu \mathrm{m}$ slices, deparaffinated, and stained with haematoxylin and eosin before coverslipping.

\section{Statistics}

When comparing parasitaemia values, $\mathrm{p}$ values were calculated using Students t-test; for analysis of survival curves, the Kaplan-Meier test was employed. In both cases, values below 0.05 were considered significant.

\section{Results}

The general approach was to establish the lowest dose required to save the mice from ECM, using the artemisinin derivatives. Per the results, the most effective drug was chosen and used to determine the latest day postinoculation (as close as possible to the time of overt ECM expression) at which treatment was still efficient. Following results depicting recrudescence, experiments were performed to determine whether recrudescent parasites displayed any resistance to the drugs used for treatment. Finally, combination therapy was administered to prevent recrudescence and achieve complete cure.

Mice were treated with the artemisinin derivatives dissolved in DMSO or administered the same volume of DMSO as a control, on different days post-inoculation. Injection of DMSO itself may partially reduce ECM and shift the pattern of disease to anemic malaria (see below). Table 2 depicts the results of an experiment in which PbA-infected female ICR mice were treated by i. p. injection of artemisinin derivatives, once a day on days 2-5 post-inoculation. No significant differences in the pattern of disease development were seen as a result of treatment, except in the case of artemiside; administration of this drug resulted in complete cure. These results also suggest that treatment with artemisinins would necessitate more than one injection per day. Despite the superior effect of artemiside, the experiments were continued using artemisone, as it has been already approved for human use [60].

In the next experiment (Figure 2), artemisone was administered i.p. as a split daily dose on days 3-6 postinoculation, to either ICR or C57BL/6 mice infected with $\mathrm{PbA} .90 \%$ of control ICR mice died of ECM by day 8 ; all mice treated with $2 \times 2.5 \mathrm{mg} / \mathrm{kg} / \mathrm{d}$ artemisone relapsed after an initial drop in parasitemia and died of
Table 2 The effect of artemisinin derivatives on the development of experimental cerebral malaria in PbAinfected ICR mice

\begin{tabular}{lccc}
\hline Compound & Dose & \% ECM & $\begin{array}{c}\text { Delay to ECM } \\
\text { (relative to } \\
\text { control) }\end{array}$ \\
\hline DMSO & $50 \mu \mathrm{l}$ & $50-90 \%^{*}$ & - \\
DHA & $5 \mathrm{mg} / \mathrm{kg} / \mathrm{d}$ & $90 \%$ & - \\
& $10 \mathrm{mg} / \mathrm{kg} / \mathrm{d}$ & $70 \%$ & - \\
& $20 \mathrm{mg} / \mathrm{kg} / \mathrm{d}$ & $60 \%$ & 2 days \\
Artesunate & $2 \times 5 \mathrm{mg} / \mathrm{kg} /$ & $65 \%$ & 9 days** \\
Artemisone & $5 \mathrm{~d} g / \mathrm{kg} / \mathrm{d}$ & $100 \%$ & 2 days \\
Artemiside & $3 \mathrm{mg} / \mathrm{kg} / \mathrm{d}$ & $\begin{array}{c}\text { Total cure, no } \\
\text { ECM }\end{array}$ & - \\
\hline
\end{tabular}

Mice ( $\mathrm{n}=10 \mathrm{mice} / \mathrm{group}$ ) were treated for two to five days post-inoculation. Death from ECM was apparent in control mice starting on day 7 postinoculation. Mice which did not die of ECM died of severe anemic malaria.

* In 3 experiments.

** Significant

${ }^{\dagger}$ No recrudescence

ECM, while the higher dose $(2 \times 5 \mathrm{mg} / \mathrm{kg} / \mathrm{d}$ artemisone $)$ was curative in all treated mice (Figure 2A). In $\mathrm{C} 57 \mathrm{Bl} / 6$ mice, $70 \%$ of DMSO-treated control mice died of ECM. Administration of $2 \times 2.5 \mathrm{mg} / \mathrm{kg} / \mathrm{d}$ artemisone led to rapid parasite clearance and complete cure in $50 \%$ of treated mice; recrudescence was observed on day 13 post-inoculation in the remaining mice, which died of ECM (Figure 2B). Treatment with $2 \times 5 \mathrm{mg} / \mathrm{kg} /$ day led to complete cure in both ICR and $\mathrm{C} 57 \mathrm{Bl} / 6$ mice. The differences in survival between all three groups (control vs. treated, and $2 \times 2.5$ vs. $2 \times 5 \mathrm{mg} / \mathrm{kg} / \mathrm{d} \mathrm{C} 57 \mathrm{Bl} / 6$ mice) were significant $(\mathrm{p}<0.01)$. Artemisone treatment significantly reduced parasitemias $(\mathrm{p}<0.001)$ and increased survival times, delaying mouse death by up to two weeks (Figure 3). In ICR mice, the increased survival time of mice treated with $2 \times 5 \mathrm{mg} / \mathrm{kg} / \mathrm{d}$ artemisone, compared to control mice, was statistically significant ( $<<0.001)$, as was the difference in survival time when treated groups were compared $(\mathrm{p}<0.001)$.

Table 3 presents a summary of experiments performed to examine the effect of treatment timing on the course of the disease. $\mathrm{C} 57 \mathrm{Bl} / 6 \mathrm{Aus}$ mice were infected with $\mathrm{PbAus}$ and administered artemisone according to different schedules. Control mice were divided into two groups: one group was not treated, while the other was injected with DMSO in parallel to the drug treatment schedule. 5/6 non-injected control mice died of ECM on days 6-9 post-inoculation; DMSO treatment for six successive days $(2 \times 25 \mu \mathrm{l} /$ day on days 3-7 and $1 \times 25 \mu \mathrm{l} /$ day on day 8 post-inoculation) reduced the occurrence of ECM to 3/6 mice (Table 3, groups 1 and 2). Mice that did not succumb to ECM died of severe anemic malaria, three weeks later and at high parasitaemias 


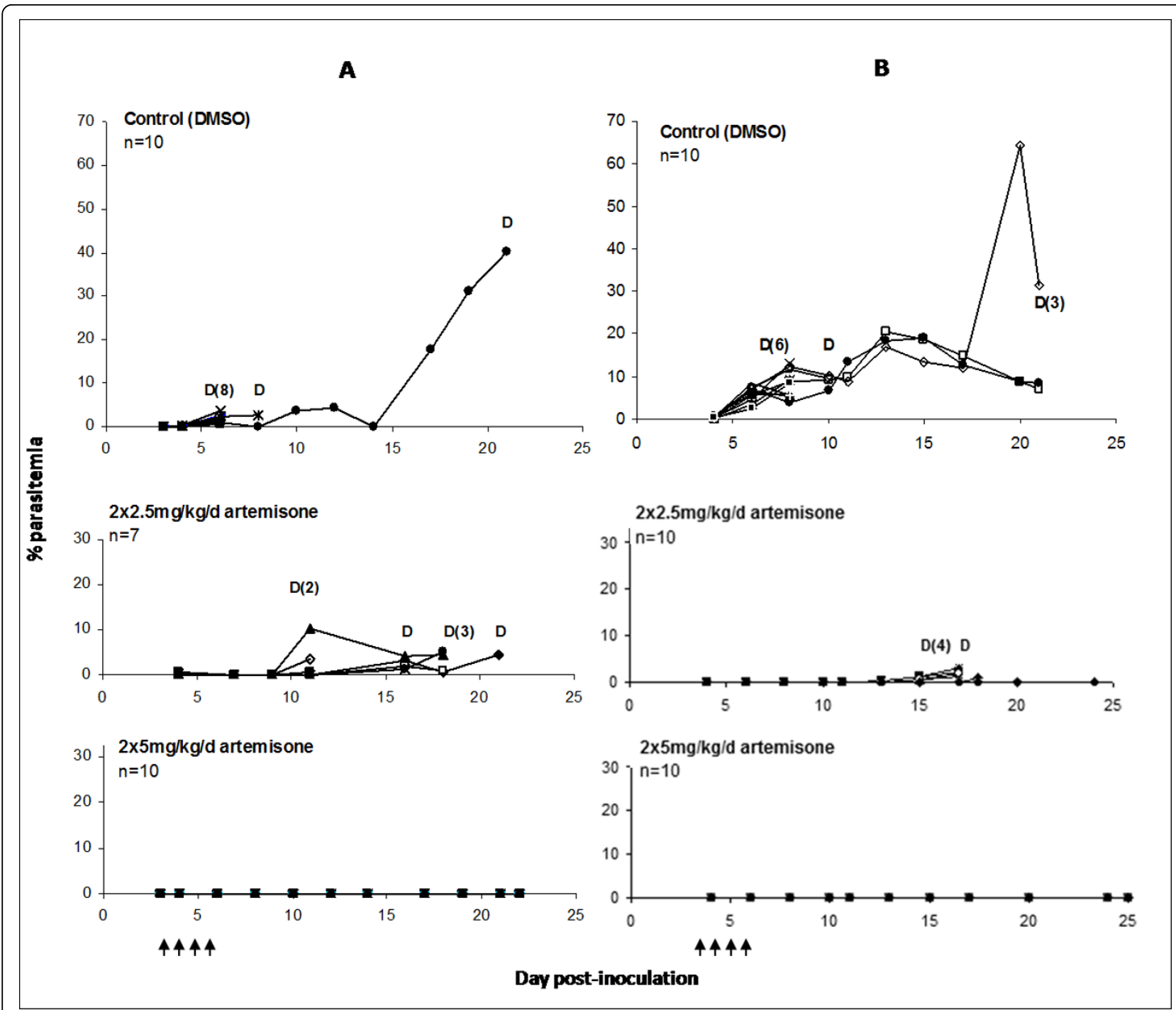

Figure 2 Development of parasitemia in ICR (A) or C57BI/6 (B) mice infected with PbA and treated with $2 \times 2.5$ or $2 \times 5 \mathrm{mg} / \mathrm{kg} / \mathrm{d}$ artemisone on days 3-6 post-inoculation. D notes mouse death; multiple deaths on a given day are noted in parentheses. Each line represents a single mouse; arrows denote treatment. ECM death in both control groups occurred on days 8-10 post-inoculation. Administration of $2 \times 2.5 \mathrm{mg} / \mathrm{kg} / \mathrm{d}$ artemisone was not curative in ICR mice, but led to complete cure in 50\% of C57BI/6 mice; treatment with $2 \times 5 \mathrm{mg} / \mathrm{kg} / \mathrm{day}$ led to complete cure in both mouse strains.

(above 50\%). For the drug-treated groups, the start of treatment was determined according to parasitaemia levels: injections began on day 3 or 4 post-inoculation, when the parasitaemia reached $1 \%$. Treatment with $2 \times$ $5 \mathrm{mg} / \mathrm{kg} /$ day artemisone on days 3-7 or 4-7, followed by a single injection $(5 \mathrm{mg} / \mathrm{kg} /$ day $)$ on day 8 postinoculation, reduced parasitaemias to below detection level and led to complete cure in the majority of the mice. In each group, one mouse recrudesced after 10 or 11 days, developed high parasitaemia and died of severe anaemic malaria. If treatment was further delayed to days 5-8 post-inoculation, there was a typical latent period followed by complete cure $(2 / 5$ mice $)$ or recrudescence and death from severe anaemic malaria (3/5 mice) (Table 3, group 5). No ECM deaths due to recrudescence were observed. Furthermore, injection of infected mice with $2 \times 20 \mathrm{mg} / \mathrm{kg} / \mathrm{d}$ artemisone at a very late stage of the disease, on days 6-8 post-inoculation (when parasitaemia was $\sim 5 \%$ ), completely eliminated the parasites and prevented ECM in all treated mice. The choice of dose was based on experiments in which $2 \times 5$ $\mathrm{mg} / \mathrm{kg}$ was curative (see below): $2 \times 20 \mathrm{mg} / \mathrm{kg}$ was used as a measure for the margin of safety and for proof of concept - that a non-toxic dose can prevent neuropathology. 6/7 control untreated mice died of ECM on day 7; the remaining mouse died of ECM on day 8 . 


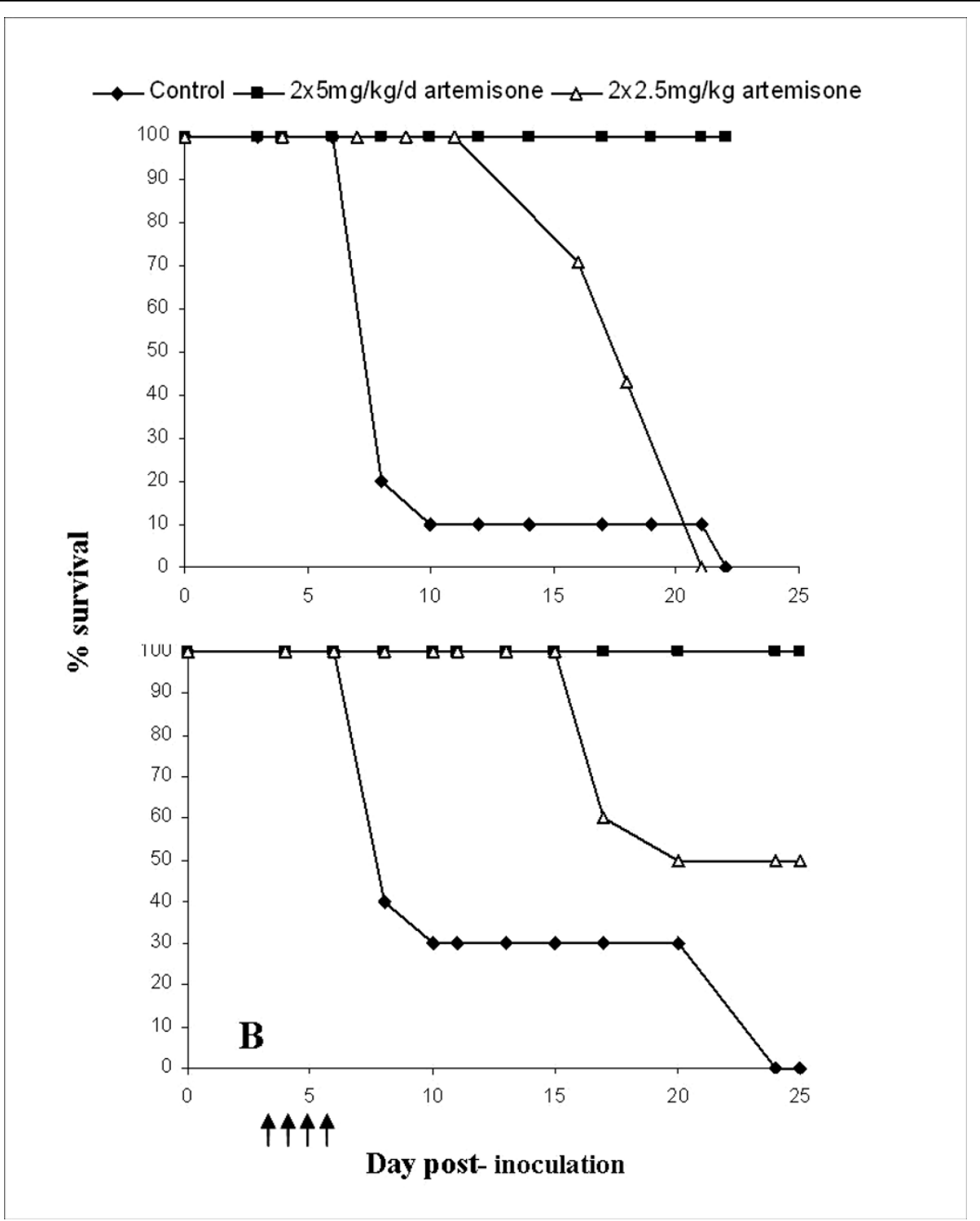

Figure 3 Survival of ICR (A) or C57BI/6 (B) mice infected with PbA and administered $2 \times 2.5$ or $2 \times 5 \mathrm{mg} / \mathrm{kg} / \mathrm{d}$ artemisone on days 3-6 post-inoculation. Significant differences in survival were seen between control and treated groups, in both ICR and C57BI/6 mice ( $p<0.01)$ : artemisone treatment delayed mouse death by up to two weeks. Arrows denote treatment.

Table 3 Disease pattern in PbAus-infected C57BL/6Aus mice treated with $2 \times 5$ mg/kg/d rtemisone

\begin{tabular}{|c|c|c|c|c|c|c|}
\hline \multirow[t]{2}{*}{ Group } & \multirow[t]{2}{*}{ Compound } & \multirow{2}{*}{$\begin{array}{c}\text { Treatment* } \\
\text { (days post-inoculation) }\end{array}$} & \multicolumn{4}{|c|}{ Disease pattern } \\
\hline & & & Latency, days & Cerebral malaria & Anemic malaria & Cured $^{* *}$ \\
\hline 1 & - & - & 0 & $5 / 6$ & $1 / 6$ & - \\
\hline 2 & DMSO $(25 \mu \mathrm{l})$ & $3-8$ & 0 & $3 / 6$ & $3 / 6$ & - \\
\hline 3 & Artemisone & $3-8$ & $10(n=1)^{\dagger}$ & $0 / 6^{+}$ & $1 / 6$ & $5 / 6^{\dagger}$ \\
\hline 4 & Artemisone & $4-8$ & $11(n=1)^{\dagger}$ & $0 / 6^{+}$ & $1 / 6$ & $5 / 6^{\dagger}$ \\
\hline 5 & Artemisone & $5-8$ & $10(n=4)^{+}$ & $0 / 5^{+}$ & $3 / 5^{\ddagger}$ & $2 / 5^{t, \neq}$ \\
\hline
\end{tabular}

* $2 \times 5 \mathrm{mg} / \mathrm{kg} / \mathrm{d}$ every day except day 8 ( 1 injection, $5 \mathrm{mg} / \mathrm{kg} / \mathrm{d})$.

** No recrudescence

${ }^{\dagger}$ Significant vs. control

${ }^{\ddagger}$ Significant vs. other artemisone-treated groups 
Histological analysis of brain sections from non-infected mice (Figure 4A) demonstrated healthy parenchyma and intact blood vessels. Neuropathological changes, namely haemorrhages and leukocyte-packed vessels, were apparent in mice one week post-PbAus inoculation (Figure 4B). In contrast, artemisone-treated mice (Figure 4C) displayed only minor haemorrhaging; vessels were intact and clear of leukocytes.

In the case of human Plasmodium infection, early detection of blood parasites (before symptoms are evident) is unlikely. Therefore the effect of delayed treatment was examined using artesunate, shown to be more effective than quinine or quinidine (both recommended as standard therapy for severe anaemic malaria in the United States) [61] and artemisone, the most recent artemisinin derivative approved for clinical trials [60]. The drugs were administered i.p. in $20 \mu \mathrm{l}$ DMSO as a split daily dose on days 7-9 post-inoculation, to C57Bl/6 mice infected with PbAus. All control mice died of ECM by day 12 post-inoculation. Following a secondary rise in parasitaemia after treatment, the mice were again injected with artesunate or artemisone, on days 20-22 post-inoculation. Figure 5 demonstrates the results of artemisone vs. artesunate therapy. Administration of $2 \times$
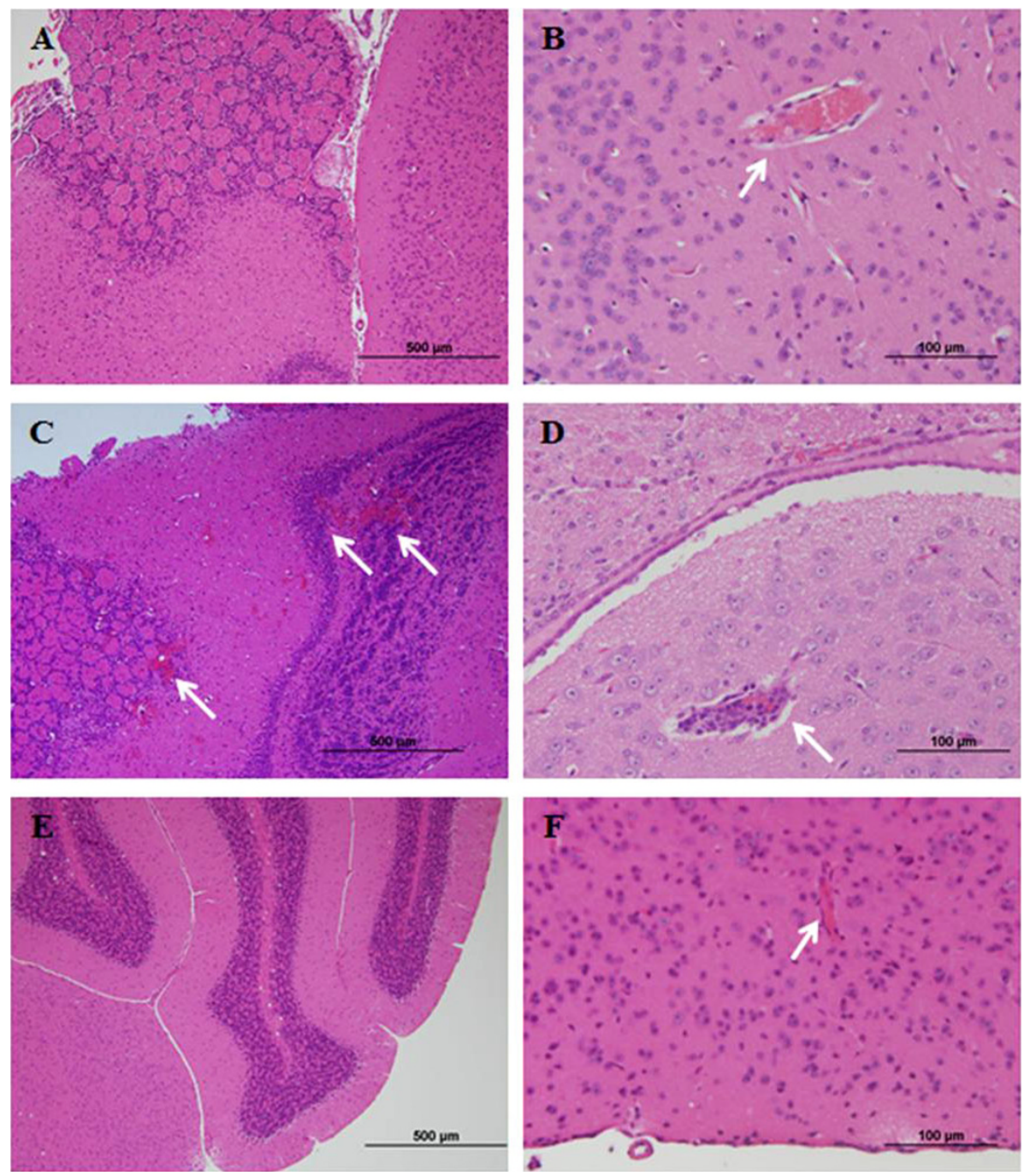

Figure 4 Brain histopathology of non-infected C57BI/6Aus mice (A, B), PbAus-infected C57BI/6Aus mice on day 6 post-inoculation (C, D), or infected artemisone-treated $\mathrm{C} 57 \mathrm{BI} / 6 \mathrm{Aus}$ mice on day 8 (E) or 13 (F) post-inoculation. All PbAus-infected control mice died of ECM on days 7-12 post-inoculation. PbAus-infected mice treated with $2 \times 20 \mathrm{mg} / \mathrm{kg} / \mathrm{d}$ artemisone on days 6-8 post-inoculation were sacrificed on days 8-13 post-inoculation and brains taken for histology. Histological analysis of brain sections from non-infected mice demonstrated healthy parenchyma and intact blood vessels. Haemorrhages and leukocyte-packed vessels were apparent in mice one week post-PbAus inoculation while artemisone-treated mice displayed only minor haemorrhaging; vessels were intact and clear of leukocytes. Arrows indicate hemorrhages and/or blood vessels. 

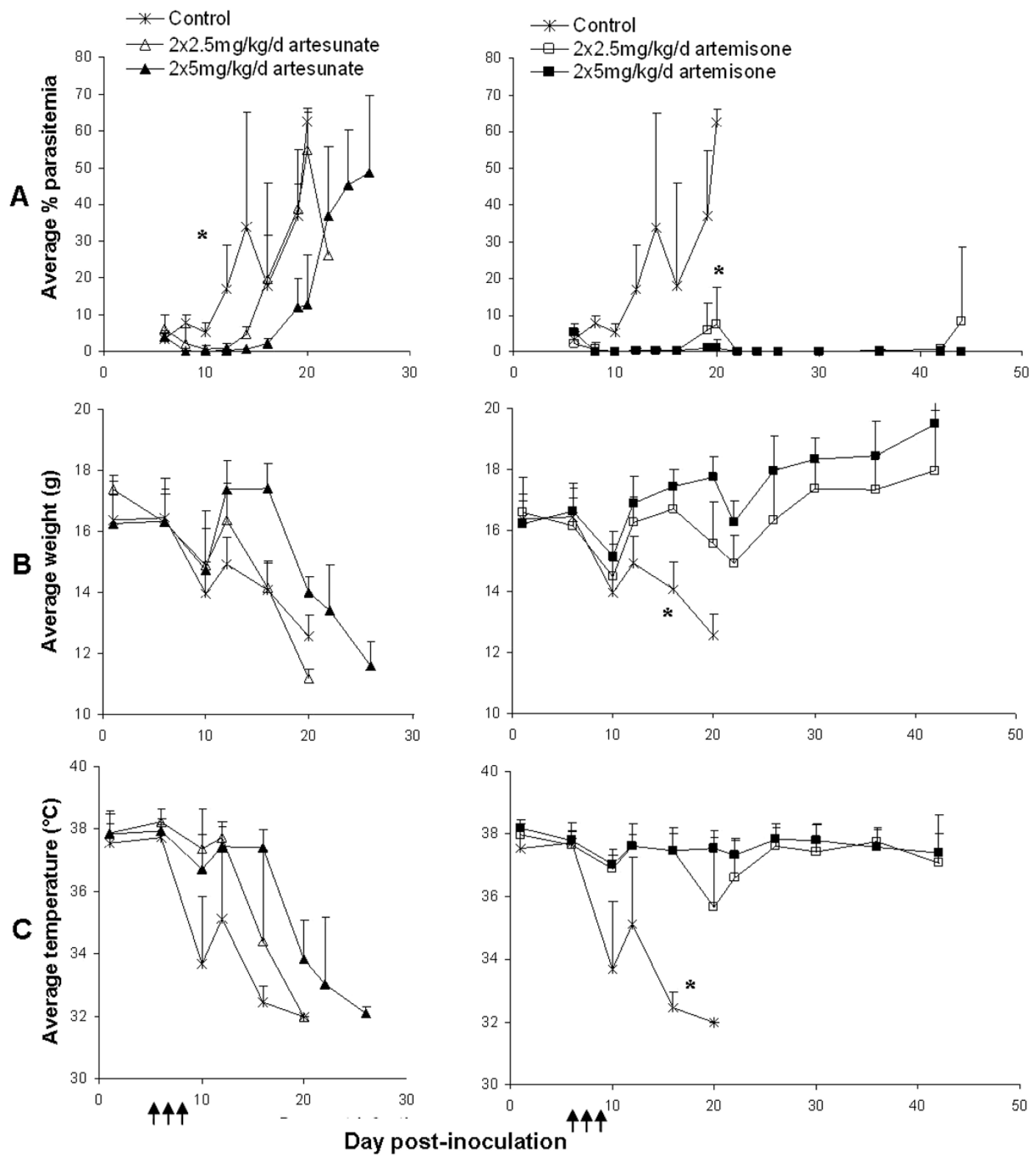

Figure 5 Parasitemias (A), weights (B), and body temperatures (C) of PbAus-infected C57BI/6 mice treated with $2 \times 2.5 \mathrm{mg} / \mathrm{kg} / \mathrm{d}$ or 2 $\times \mathbf{5 ~} \mathbf{~ g} / \mathbf{k g} / \mathbf{d}$ artesunate or artemisone. Injections (arrows) were given on days 7-9 post-inoculation; control mice were administered $2 \times 20 \mu \mathrm{l}$ DMSO per day. ${ }^{*} \mathrm{p}<0.001$, control vs. treated mice. Administration of $2 \times 2.5 \mathrm{mg} / \mathrm{kg} / \mathrm{d}$ artesunate did not prevent ECM death; $2 \times 5 \mathrm{mg} / \mathrm{kg} / \mathrm{d}$ artesunate prevented ECM in most mice and delayed death from anemic malaria by approximately one week. Both doses of artemisone prevented ECM in all treated mice, delayed recrudescence and prevented death. Changes in temperature and weight were in accordance with disease severity, and the differences in overall group scores. Average values \pm SD (error bars) are presented.

$2.5 \mathrm{mg} / \mathrm{kg} / \mathrm{d}$ artesunate slightly delayed but in general did not prevent ECM death $(\mathrm{p}=0.4) ; 2 \times 5 \mathrm{mg} / \mathrm{kg} / \mathrm{d}$ artesunate prevented ECM in most mice $(\mathrm{p}<0.0001)$ and delayed death from anemic malaria by approximately one week $(p<0.0001)$. In contrast, both doses of artemisone prevented ECM in all treated mice, delayed recrudescence and prevented death (in 5/8 and 8/8 mice for $2 \times 2.5 \mathrm{mg} / \mathrm{kg} / \mathrm{d}$ and $2 \times 5 \mathrm{mg} / \mathrm{kg} / \mathrm{d} ; \mathrm{p}<0.0001$ for treated vs. control mice and for $2 \times 2.5$ vs. $2 \times 5 \mathrm{mg} /$ $\mathrm{kg} / \mathrm{d}$ artemisone, respectively; Figure 5A, Table 4). $2 \times$ $2.5 \mathrm{mg} / \mathrm{kg} / \mathrm{d}$ artemisone was more effective in delaying mouse death than the higher dose of artesunate tested $(\mathrm{p}<0.01)$. Changes in mouse temperature (Figure 5B) and weight (Figure $5 \mathrm{C}$ ) were in accordance with disease 
Table 4 Disease pattern in PbAus-infected C57BL/6 mice treated with artesunate or artemisone twice a day, on days 7-9 post-inoculation

\begin{tabular}{|c|c|c|c|c|}
\hline \multirow[t]{2}{*}{ Compound } & \multirow[t]{2}{*}{ Dose } & \multicolumn{3}{|c|}{ Infection outcome } \\
\hline & & $\begin{array}{c}\text { Cerebral } \\
\text { malaria }\end{array}$ & $\begin{array}{l}\text { Anemic } \\
\text { malaria }\end{array}$ & Cured \\
\hline DMSO & $20 \mu \mathrm{l}$ & $4 / 8$ & $4 / 8$ & $0 / 8$ \\
\hline \multirow[t]{2}{*}{ Artesunate } & $\begin{array}{l}2 \times 2.5 \mathrm{mg} / \mathrm{kg} / \\
\mathrm{d}\end{array}$ & $6 / 8$ & $2 / 8$ & $0 / 8$ \\
\hline & $2 \times 5 \mathrm{mg} / \mathrm{kg} / \mathrm{d}$ & $1 / 8^{*}$ & $7 / 8^{*}$ & $0 / 8$ \\
\hline \multirow[t]{2}{*}{ Artemisone } & $\begin{array}{l}2 \times 2.5 \mathrm{mg} / \mathrm{kg} / \\
\mathrm{d}\end{array}$ & $0 / 8^{*}$ & $3 / 8$ & $5 / 8^{*+}$ \\
\hline & $2 \times 5 \mathrm{mg} / \mathrm{kg} / \mathrm{d}$ & $0 / 8^{*}$ & $0 / 8^{*+}$ & $8 / 8^{*+}$ \\
\hline
\end{tabular}

*Significant vs. control.

${ }^{\dagger}$ Significant vs. artesunate. severity, and the differences in overall group scores $(\mathrm{p}<$ 0.01 ). Figure 6 clearly demonstrate the superior effect of artemisone over artesunate.

The major limitation of artemisinin-type drugs is their short half-life, which necessitates frequent administration; this leads to non-compliance, recrudescence, and possibly the development of resistance [24,62]. As a result, the World Health Organization recommends that these drugs be administered together with a long halflife anti-plasmodial drug (artemisinin combination therapy; ACT). Our experiments examined whether recrudescent parasites that appeared following artemisone therapy displayed any drug resistance. Recrudescent parasites (referred to as 'recrudescent PbAus') were
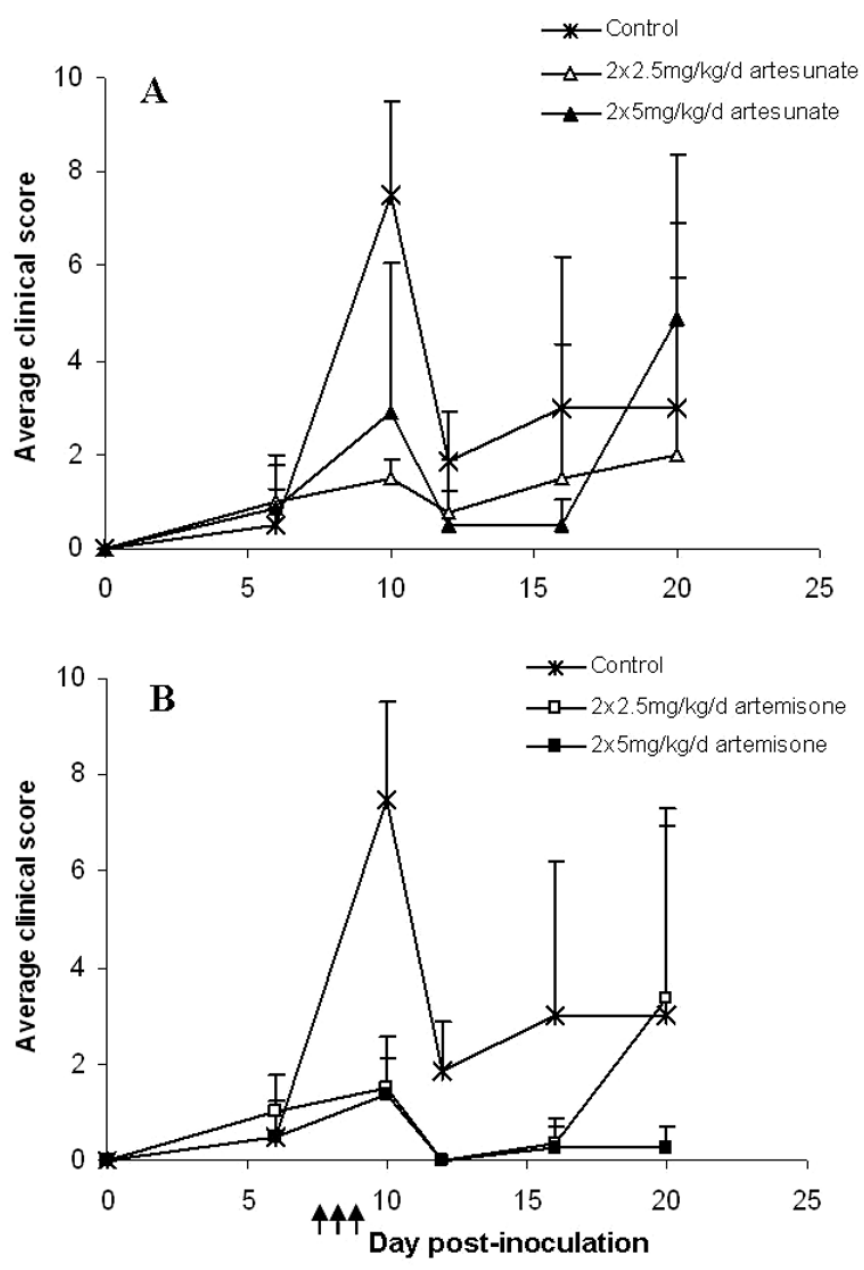

Figure 6 Overall group scores for PbAus-infected C57BL/6 mice treated with artesunate (A) or artemisone (B), twice a day on days 7-9 post-inoculation. Significant differences were seen between the control group and mice treated with $2 \times 5 \mathrm{mg} / \mathrm{kg} / \mathrm{d}$ artesunate $(\mathrm{p}<0.05)$ or artemisone (both doses; $\mathrm{p}<0.001$ ). The effects of $2 \times 2.5 \mathrm{mg} / \mathrm{kg} / \mathrm{d}$ artesunate or artemisone were similar, but artemisone was significantly more effective than artesunate, at the higher dose $(p<0.001)$. Average values \pm SD (error bars) are presented. Arrows represent injections. 
isolated from peripheral blood of $\mathrm{C} 57 \mathrm{Bl} / 6$ mice, which had previously undergone a three-day treatment with 2 $\times 5 \mathrm{mg} / \mathrm{kg} / \mathrm{d}$ artemisone, and were injected to naïve mice. After an additional passage, the recrudescent $\mathrm{PbAus}$ parasites were injected to $\mathrm{C} 57 \mathrm{Bl} / 6$ mice, and artemisone administered at $2 \times 2.5 \mathrm{mg} / \mathrm{kg} / \mathrm{d}$; control mice were administered DMSO. Two additional groups of mice were infected with non-recrudescent $\mathrm{PbAus}$ and similarly injected with artemisone or DMSO. The results demonstrate a lack of parasite resistance to artemisone (Figure 7). No significant differences in parasitaemia were seen when comparing the two control groups. Administration of $2 \times 2.5 \mathrm{mg} / \mathrm{kg} / \mathrm{d}$ artemisone caused a similar, rapid drop in parasitaemia in both PbAus-

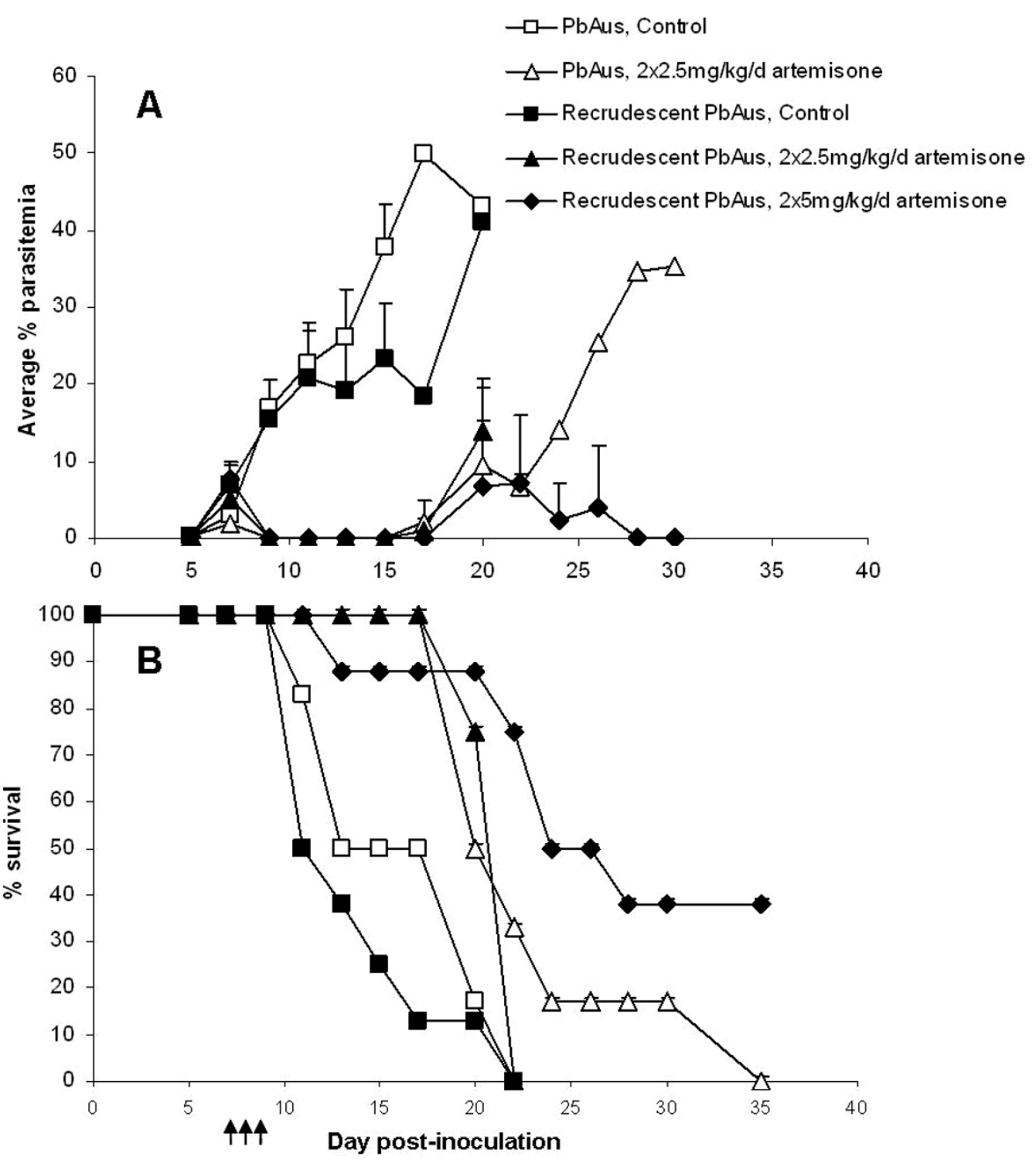

Figure 7 Average parasitemias (A) and survival (B) of C57BL/6 mice infected with recrudescent PbAus, or PbAus, and administered artemisone twice a day, on days 7-9 post-inoculation. Recrudescent parasites were isolated from peripheral blood of C57BI/6 mice previously treated with $2 \times 5 \mathrm{mg} / \mathrm{kg} / \mathrm{d}$ artemisone, and were injected to naïve mice. After an additional passage, the recrudescent parasites were injected to C57BI/6 mice, and artemisone administered at $2 \times 2.5 \mathrm{mg} / \mathrm{kg} / \mathrm{d}$. Two additional groups of mice were infected with non-recrudescent PbAus and similarly treated. No significant differences were seen in either parasitemias or survival when comparing control PbAus- and recrudescent PbAus-infected mice. Differences in parasitemias between control and treated groups were significant $(p<0.001)$, as were the differences in survival rates. Average values \pm SD (error bars) are presented. Arrows represent injections. 
and recrudescent PbAus-infected mice (Figure 7A). No significant difference in survival was seen when comparing the two control groups $(\mathrm{p}=0.3)$, and when comparing treated groups (Figure 7B). An increased dose of $2 \times 5 \mathrm{mg} / \mathrm{kg} / \mathrm{d}$ led to complete cure in $3 / 7$ mice (Figure 7B).
A further experiment was performed in order to examine the efficiency of artemisone-chloroquine combination therapy, to prevent the cerebral symptoms and achieve complete parasite clearance (Figure 8). $\mathrm{C} 57 \mathrm{Bl} / 6$ mice were infected with $\mathrm{PbAus}$ as previously described, and treated on days 7-9 post-inoculation

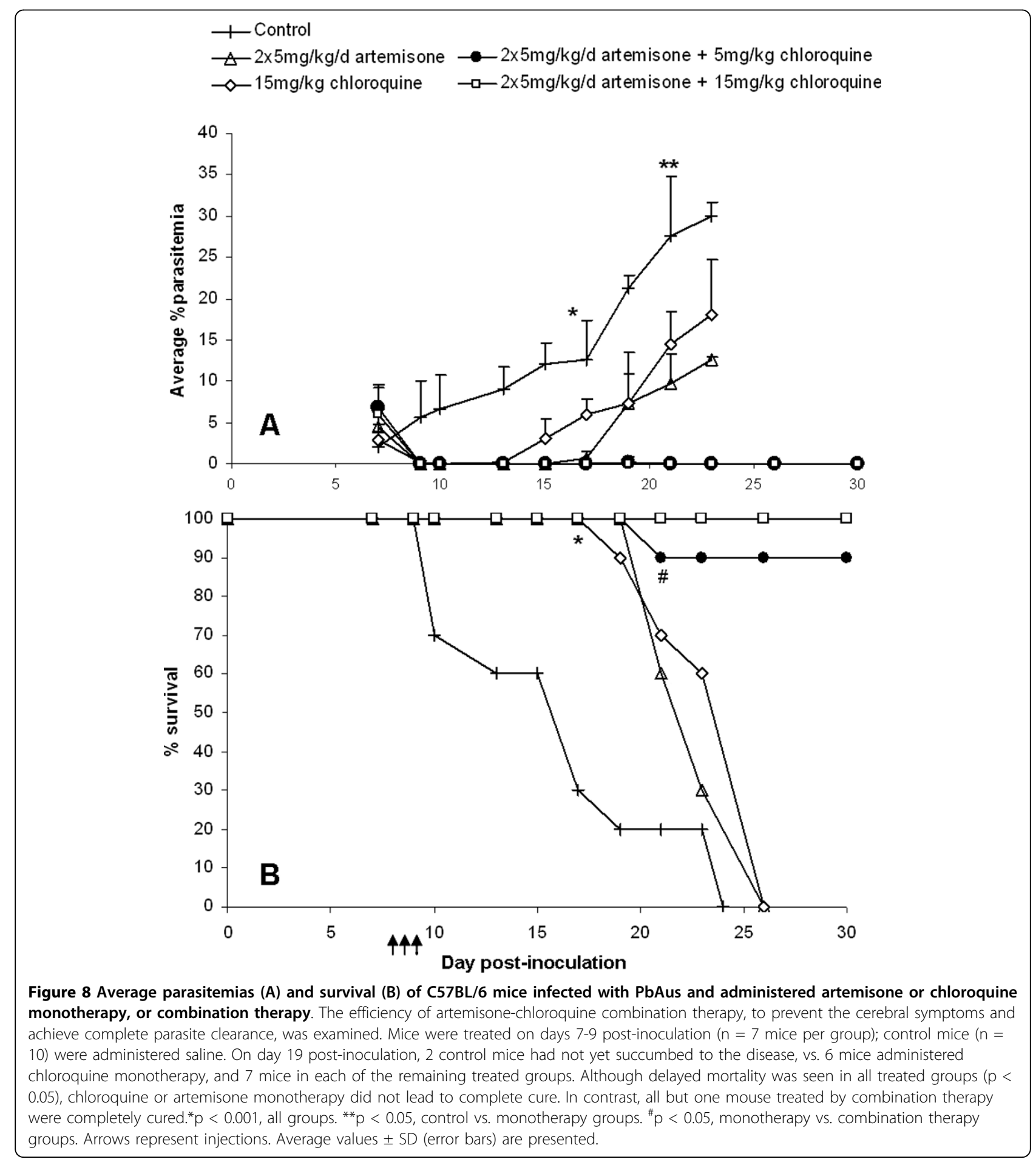


with $2 \times 5 \mathrm{mg} / \mathrm{kg} / \mathrm{d}$ artemisone, $15 \mathrm{mg} / \mathrm{kg} / \mathrm{d}$ chloroquine, or a combination of $2 \times 5 \mathrm{mg} / \mathrm{kg} / \mathrm{d}$ artemisone and 5 or $15 \mathrm{mg} / \mathrm{kg} / \mathrm{d}$ chloroquine. $80 \%$ of control mice died of ECM, whereas monotherapy with either drug caused a drop to non-detectable parasitaemia levels by day 10 post-inoculation (Figure 8A). Administration of artemisone was more effective than chloroquine treatment: parasitaemia levels in all artemisone-treated mice were below detection by the end of treatment, and recrudescence was observed starting on day 15 post-inoculation. In contrast, parasitaemia levels of mice administered chloroquine dropped to zero only on day 10 , and recrudescence was seen starting on day 13 post-inoculation. Although delayed mortality was seen in all treated groups $(\mathrm{p}<0.05)$ (Figure $8 \mathrm{~B})$, chloroquine or artemisone monotherapy did not lead to complete cure. The majority of mice, in both cases, succumbed to ECM, and the rest died later at high parasitaemia. Except for one, all mice treated by combination therapy were completely cured. No significant difference in clinical score was seen during the ECM phase when comparing control, artemisone- and chloroquine-treated groups (Figure 9A). In contrast, significantly lower scores were seen in mice treated with artemisone and chloroquine throughout the experiment (Figure 9B).

\section{Discussion}

In this research, the efficacy of several artemisinin derivatives was examined for treatment of ECM in ICR and $\mathrm{C} 57 \mathrm{BL}$ mice. The most widely used model for CM utilizes inbred (C57BL) mice. The decision to use genetically heterogenous ICR mice in our research, as an additional model for CM, was made in order to enable a more accurate reflection of human CM susceptibility and the possible effect of treatment. The validity of ECM in outbred mice as a model for CM has previously been demonstrated [41,63-65]. Artemiside and artemisone were shown to be more effective than DHA and artesunate, two artemisinin derivatives used in anti-malarial artemisinin-based combination therapy. In all experiments, treatment with artemisone led to complete cure, or reduced parasitaemia to undetectable levels; recrudescence was followed by death from either anaemic or cerebral malaria. In these cases, the significant delay to the time of death from anaemic malaria, or to the appearance of cerebral symptoms, may open a considerable time window for adequate treatment. A steady state latency, in which non-detectable levels of parasites remain in the blood, has been described in cases of human $P$. falciparum infection [65]. As demonstrated, the recrudescent parasites could also be completely eliminated by repeating the artemisone treatment.

The results with artemisone demonstrate that complete cure may be achieved even when treatment is started at late stages of pathogenesis, 6 days postinoculation. These findings are especially important, as human malaria is diagnosed only after clinical symptoms are apparent, and especially so if the rapid process of $\mathrm{CM}$ has been initiated. Furthermore, co-administration of artemisone with low doses of chloroquine prevented recrudescence and led to complete cure in all mice. Recrudescence that appeared after monotherapy did not cause any short-term drug resistance, as parasites isolated from the recrudescent mice were fully susceptible to artemisone.

The successful use of artemisone in combination with chloroquine, to which most strains of $P$. falciparum are resistant, may be analogous to the combination of proguanil and atovaquone (Malarone ${ }^{\oplus}$ ). Although P. falciparum is resistant to both atovaquone and proguanil, the parasite is sensitive to Malarone ${ }^{\curvearrowleft}$, which is used for both prophylaxis and treatment. Similarly, combination of artemisone with a partner drug to which resistance has developed may enable the latters reintroduction.

Although slight antagonism between artemisone and chloroquine has been reported in in vitro tests against P. falciparum [66], synergism or no interaction has been observed when the drugs were tested in vivo against Plasmodium yoelii NS or P. berghei NY, respectively. The in vivo experiments were based on the Peter's fourday test, in which mice are treated on the first day postinoculation and for an additional three days thereafter; the analysis of results is based on blood smears taken on day 5 post-inoculation. This approach does not reflect the final results of the treatment (i.e. the fate of the animals) or provide any indication of the immune responses of the infected animals. Therefore, the Peter's four-day test is inadequate for estimation of the effect of drug treatment on severe (cerebral) malaria, where pathogenesis is most pronounced a week or more after infection and pathology (or lack of pathology) is the result of a prolonged innate immune response [34] and early acquired immunity.

Artemiside appeared to be even more effective than artemisone, but this substance has yet to be submitted to preclinical toxicological evaluation. Nevertheless, although it does display neurotoxicity in in vitro assays with neuronal cell lines [34], this is substantially less than that of DHA. It is approximately three times more active than artemisone in vitro against $P$. falciparum, and its therapeutic index suggests that it will be usable in a clinical setting. In principle it may act as a prodrug for 


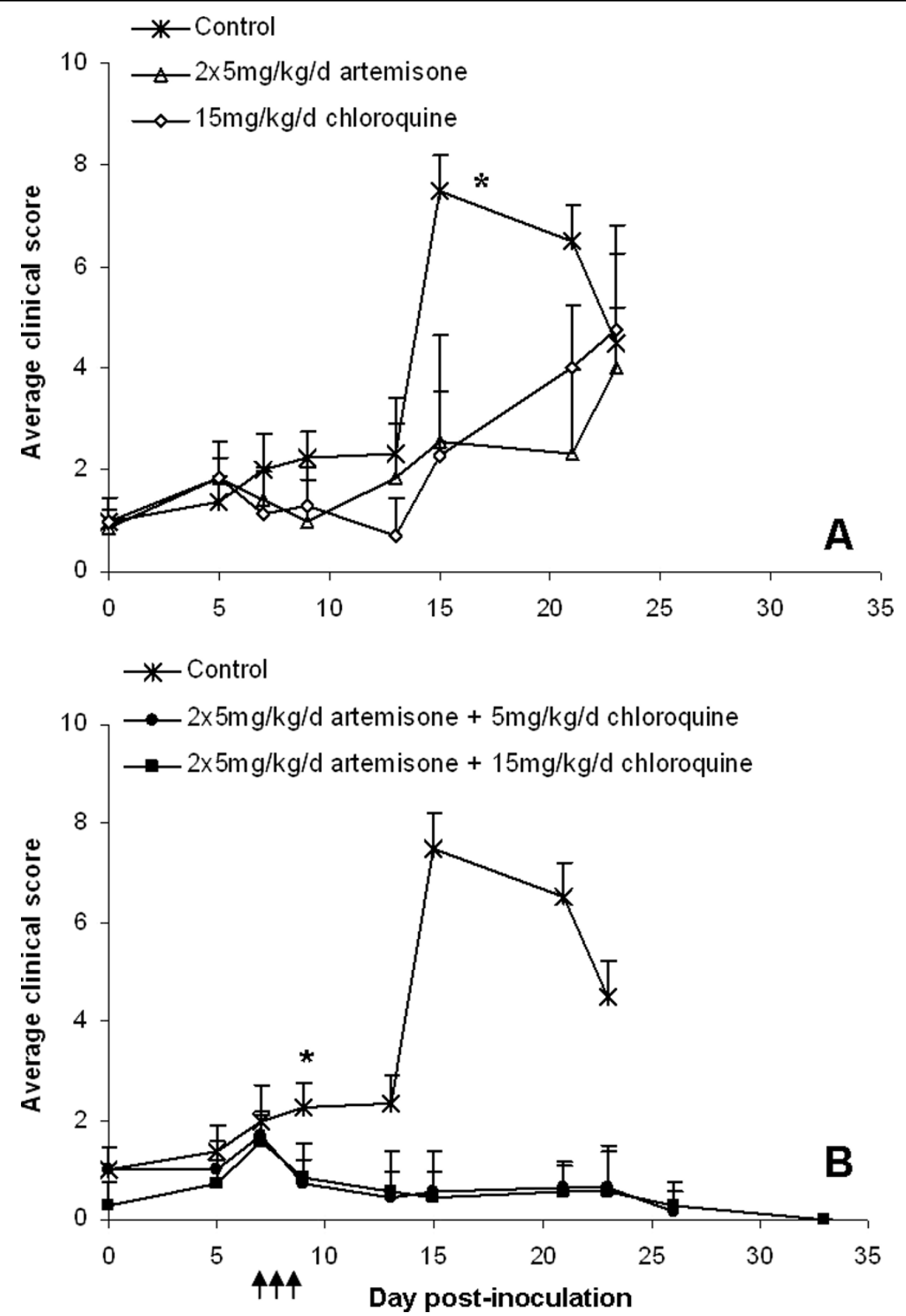

Figure 9 Average clinical scores of C57BL/6 mice infected with PbAus and administered artemisone or chloroquine monotherapy (A), or combination therapy (B). No significant difference in clinical score was seen during the ECM phase when comparing control, artemisoneand chloroquine-treated groups. In contrast, significantly lower scores were seen in mice treated with artemisone and chloroquine throughout the experiment. ${ }^{*} p<0.05$, control vs. treated groups. Average values \pm SD (error bars) are presented. Arrows represent injections.

artemisone through oxidation of the thiomorpholine ring to the S, S-dioxide of artemisone.

\section{Conclusions}

The results show that artemiside and artemisone are the two most effective artemisinin derivatives. Administration of artemisone may result in complete cure even when treatment is started at late stages of pathogenesis; recrudescence that appeared after monotherapy did not cause any short-term drug resistance. Co-administration of artemisone with low doses of chloroquine prevented recrudescence and led to complete cure in all mice. Combination of artemisone with a partner drug to which resistance has developed may enable 
reintroduction of the latter. Artemiside, found even more effective than artemisone, may represent a new option for artemisinin-based anti-malarial therapy.

\begin{abstract}
Acknowledgements
This work at The Hebrew University was supported by grants from The Gretel B. Bloch Charitable Trust, The Sir Zelman Cowen Universities Fund, the Barenholz Fund and the Israel Science Foundation.

Work at Hong Kong University of Science and Technology (HKUST) was carried out in the Open Laboratory of Chemical Biology of the Institute of Molecular Technology for Drug Discovery and Synthesis with financial support from the Government of the HKSAR University Grants Committee Areas of Excellence Fund, Projects No. AoE P/10-01/01-02-I, AOE/P-10/01-2-II and the University Grants Council Grants No. HKUST 6493/06 M and 600507. The work at the University of Sydney was supported by the National Health and Medical Research Council of Australia and the Sir Zelman Cowen Universities Fund.
\end{abstract}

\section{Author details}

'Department of Microbiology and Molecular Genetics, The Hebrew University of Jerusalem, Jerusalem, 91120, Israel. ${ }^{2}$ Laboratory of Membrane and Liposome Research, Department of Biochemistry, Institute for Medical Research - Israel-Canada, The Hebrew University of Jerusalem - Hadassah Medical School, Jerusalem, Israel. ${ }^{3}$ Department of Pathology and Bosch Institute, The University of Sydney, Sydney, Australia. ${ }^{4}$ Department of Chemistry, Institute of Molecular Technology for Drug Discovery and Synthesis, The Hong Kong University of Science and Technology, Clear Water Bay, Kowloon, Hong Kong.

\section{Authors' contributions}

JHWG participated in experiments and preparation of the manuscript. ABM, JAMQ, HWC and WCC participated in experiments. $\mathrm{NH}$ and RKH supervised the study and participated in preparation of the manuscript. JG and YB initiated and coordinated the study. All authors read and approved the final manuscript.

\section{Competing interests}

The authors declare that they have no competing interests.

Received: 5 May 2010 Accepted: 9 August 2010

Published: 9 August 2010

\section{References}

1. Woodrow CJ, Haynes RK, Krishna S: Artemisinins. Postgrad Med J 2005, 81:71-78.

2. Mita T, Tanabe K, Kita K: Spread and evolution of Plasmodium falciparum drug resistance. Parasitol Int 2009, 58:201-209.

3. Roepe PD: Molecular and physiologic basis of quinoline drug resistance in Plasmodium falciparum malaria. Future Microbiol 2009, 4:441-455.

4. Wisedpanichkij R, Chaijaroenkul W, Sangsuwan P, Tantisawat J, Boonprasert K, Na-Bangchang K: In vitro antimalarial interactions between mefloquine and cytochrome P450 inhibitors. Acta Trop 2009, 112:12-15.

5. Nkrumah $\sqcup$, Riegelhaupt PM, Moura P, Johnson DJ, Patel J, Hayton K, Ferdig MT, Wellems TE, Akabas MH, Fidock DA: Probing the multifactorial basis of Plasmodium falciparum quinine resistance: evidence for a strainspecific contribution of the sodium-proton exchanger PfNHE. Mol Biochem Parasitol 2009, 165:122-131.

6. Golenser J, McQuillan J, Hee L, Mitchell AJ, Hunt NH: Conventional and experimental treatment of cerebral malaria. Int J Parasitol 2006, 36:583-593.

7. Haynes RK, Fugmann B, Stetter J, Rieckmann K, Heilmann HD, Chan HW, Cheung MK, Lam WL, Wong HN, Croft SL, Vivas L, Rattray L, Stewart L, Peters W, Robinson BL, Edstein MD, Kotecka B, Kyle DE, Beckermann B, Gerisch M, Radtke M, Schmuck G, Steinke W, Wollborn U, Schmeer K, Römer A: Artemisone-a highly active antimalarial drug of the artemisinin class. Angew Chem Int Ed Eng 2006, 45:2082-2088.

8. Haynes RK, Ho WY, Chan HW, Fugmann B, Stetter J, Croft SL, Vivas L, Peters W, Robinson BL: Highly antimalaria-active artemisinin derivatives: biological activity does not correlate with chemical reactivity. Angew Chem 2004, 116:1405-1409.

9. Haynes RK, Krishna S: Artemisinins: activities and actions. Microbes Infect 2004, 6:1339-1346.

10. Olliaro PL, Haynes RK, Meunier B, Yuthavong Y: Possible modes of action of the artemisinin-type compounds. Trends Parasitol 2001, 17:122-126.

11. Wells TNC, Alonso PL, Gutteridge WE: New medicines to improve control and contribute to the eradication of malaria. Nat Rev Drug Disc 2009, 8:879-891.

12. O'Neill PM, Chadwick J, Rawe SL, Rappoport Z, (ed.): Chemistry of Peroxides. Wiley, Chichester, UK 2006, 2.

13. Kannan R, Kumar K, Sahal D, Kukreti S, Chauhan VS: Reaction of artemisinin with haemoglobin: implications for antimalarial activity. Biochem J 2005, 385:409-418.

14. Robert A, Benoit-Vicala F, Meunier B: The key role of heme to trigger the antimalarial activity of trioxanes. Coord Chem Rev 2005, 249:1927-1936.

15. Coghi P, Basilico N, Taramelli D, Chan WC, Haynes RK, Monti D: Interaction of artemisinins with oxyhemoglobin $\mathrm{Hb}-\mathrm{Fe}^{\prime \prime}, \mathrm{Hb}-\mathrm{Fe}^{\prime \prime}, \mathrm{CarboxyHb}-\mathrm{Fe}$ ", Heme-Fe", and carboxyheme Fell: significance for mode of action and implications for therapy of cerebral malaria. ChemMedChem 2009, 4:2045-2053.

16. Haynes RK, Chan WC, Lung CM, Uhlemann AC, Eckstein U, Taramelli D, Parapini S, Monti D, Krishna S: The Fe ${ }^{2+}$-mediated decomposition, PfATP6binding and antimalarial activities of artemisone and other artemisinins: the unlikelihood of C-centered radicals as bioactive intermediates. ChemMedChem 2007, 2:1480-1497.

17. Haynes RK, Schmuck G: Neurotoxic mode of action of artemisinin Antimicrob Agents Chemothe 2002, , 46: 821-827.

18. Krungkrai SR, Yuthavong Y: The antimalarial action on Plasmodium falciparum of qinghaosu and artesunate in combination with agents which modulate oxidant stress. Trans R Soc Trop Med Hyg 1987, 81:710-714.

19. Ittarat W, Sreepian A, Srisarin A, Pathepchotivong K: Effect of dihydroartemisinin on the antioxidant capacity of $P$. falciparum-infected erythrocytes. Southeast Asian Trop Med Public Health 2003, 34:744-750.

20. Li W, Mo W, Shen D, Sun L, Wang J, Lu S, Gitschier JM, Zhou B: Yeast model uncovers dual roles of mitochondria in action of artemisinin. PLOS Genet 2005, 1:e36.

21. Li PC, Lam E, Roos WP, Zdzienicka MZ, Kaina B, Efferth T: Artesunate derived from traditional Chinese medicine induces DNA damage and repair. Cancer Res 2008, 68:4347-4351.

22. Eckstein-Ludwig U, Webb RJ, van Goethem IDA, East JM, Lee AG, Kimura M, O'Neill PM, Bray PG, Ward SA, Krishna S: Artemisinins target the SERCA of Plasmodium falciparum. Nature 2003, 424:957-961.

23. Hoppe HC, van Schalkwyk DA, Wiehart UIM, Meredith SA, Egan J, Weber BW: Antimalarial quinolines and artemisinin inhibit endocytosis in Plasmodium falciparum. Antimicrob Agents Chemother 2004, 48:2370-2378.

24. Dondorp AM, Nosten F, Yi P, Das D, Phyo AP, Tarning J, Lwin KM, Ariey F, Hanpithakpong W, Lee SJ, Ringwald P, Silamut K, Imwong M, Chotivanich $K_{\text {, }}$ Lim P, Herdman T, An SS, Yeung S, Singhasivanon P, Day NP, Lindegardh N, Socheat $\mathrm{D}$, White $\mathrm{NJ}$ : Artemisinin resistance in Plasmodium falciparum malaria. N Eng J Med 2009, 361:455-467.

25. Egan TJ: Artemisinin-resistant Plasmodium falciparum: can the genie be put back in the bottle? Future Microbiol 2009, 4:637-639.

26. Jambou R, Legrand E, Niang M, Khim N, Lim P, Volney B, Ekala MT, Bouchier C, Esterre P, Fandeur T, Mercereau-Puijalon O: Resistance of Plasmodium falciparum field isolates to in-vitro artemether and point mutations of the SERCA-type PfATPase6. Lancet 2005, 366:1960-1963.

27. Burk O, Arnold KA, Nussler AK, Schaeffeler E, Efimova E, Avery BA, Avery MA, Fromm MF, Eichelbaum M: Antimalarial artemisinin drugs induce cytochrome P450 and MDR1 expression by activation of xenosensors pregnane $\mathrm{X}$ receptor and constitutive androstane receptor. Mol Pharmacol 2005, 67:1954-1965.

28. Olliaro PL, Taylor WR: Developing artemisinin based drug combinations for the treatment of drug resistant falciparum malaria: A review. J Postgrad Med 2002, 50:40-44.

29. Sibley $\mathrm{CH}$, Barnes $\mathrm{KI}$, Watkins WM, Plowe CV: A network to monitor antimalarial drug resistance: a plan for moving forward. Trends Parasitol 2008, 24:43-48.

30. White NJ: Qinghaosu (artemisinin): the price of success. Science 2008, 320:330-334 
31. Sinclair D, Zani B, Donegan S, Olliaro P, Garner P: Artemisinin-based combination therapy for treating uncomplicated malaria. Cochrane Database Syst Rev 2009, 8:CD007483.

32. Thompson CA: First artemisinin-based antimalarial combination approved for U.S. market. Am J Health Syst Pharm 2009, 66:880.

33. Schofield L, Grau GE: Immunological processes in malaria pathogenesis. Nat Rev Immunol 2005, 5:722-735.

34. Hunt NH, Golenser J, Chan-Ling T, Parekh S, Rae C, Potter S, Medana IM, Miu J, Ball HJ: Immunopathogenesis of cerebral malaria. Int J Parasitol 2006, 36:569-582.

35. Yañez DM, Manning DD, Cooley AJ, Weidanz WP, van der Heyde HC: Participation of lymphocyte subpopulations in the pathogenesis of experimental murine cerebral malaria. J Immunol 1996, 157:1620-1624.

36. Potter S, Chaudhri G, Hansen A, Hunt NH: Fas and perforin contribute to the pathogenesis of murine cerebral malaria. Redox Rep 1999, 4:333-335.

37. Belnoue E, Kayibanda M, Vigario AM, Deschemin JC, van Rooijen N, Viguier $M$, Snounou $G$, Rénia $L$ : On the pathogenic role of brainsequestered alphabeta CD8+ T cells in experimental cerebral malaria. Immunol 2002, 169:6369-6375.

38. Nitcheu J, Bonduelle O, Combadiere C, Tefit M, Seilhean D, Mazier D, Combadiere B: Perforin-dependent brain-infiltrating cytotoxic CD8+ T lymphocytes mediate experimental cerebral malaria pathogenesis. J Immunol 2003, 170:2221-2228.

39. Coltel N, Combes V, Hunt NH, Grau GE: Cerebral malaria - a neurovascular pathology with many riddles still to be solved. Curr Neurovasc Res 2004, 1:91-110.

40. van der Heyde HC, Nolan J, Combes V, Gramaglia I, Grau GE: A unified hypothesis for the genesis of cerebral malaria: sequestration, inflammation and hemostasis leading to microcirculatory dysfunction. Trends Parasitol 2006, 22:503-508.

41. Hunt NH, Grau GE: Cytokines: accelerators and brakes in the pathogenesis of cerebral malaria. Trends Immunol 2003, 249:491-499.

42. Randall LM, Amante FH, Zhou Y, Stanley AC, Haque A, Rivera F, Pfeffer K, Scheu S, Hill GR, Tamada K, Engwerda CR: Cutting Edge: Selective blockade of LIGHT-lymphotoxin beta receptor signaling protects mice from experimental cerebral malaria caused by Plasmodium berghei ANKA. J Immunol 2008, 181:7458-7462.

43. Veerasubramanian P, Gosi P, Limsomwong C, Walsh DS: Artesunate and a major metabolite, dihydroartemisinin, diminish mitogen-induced lymphocyte proliferation and activation. Southeast Asian J Trop Med Public Health 2006, 37:838-847.

44. Wang Z, Qiu J, Guo TB, Liu A, Wang Y, Li Y, Zhang JZ: Anti-inflammatory properties and regulatory mechanism of a novel derivative of artemisinin in experimental autoimmune encephalomyelitis. J Immunol 2007, 179:5958-5965

45. Wang JX, Tang W, Shi LP, Wan J, Zhou R, Ni J, Fu YF, Yang YF, Li Y, Zuo JP: Investigation of the immunosuppressive activity of artemether on T-cell activation and proliferation. Br J Pharmacol 2007, 150:652-661.

46. Xu H, He Y, Yang $X$, Liang L, Zhan Z, Ye Y, Yang X, Lian F, Sun L: Antimalarial agent artesunate inhibits TNF-alpha-induced production of proinflammatory cytokines via inhibition of NF-kappaB and PI3 kinase/ Akt signal pathway in human rheumatoid arthritis fibroblast-like synoviocytes. Rheumatology (Oxford) 2007, 46:920-926.

47. Thumwood CM, Hunt NH, Clark IA, Cowden WB: Breakdown of the bloodbrain barrier in murine cerebral malaria. Parasitology 1998, 96:579-589.

48. Neill AL, Hunt NH: Effects of endotoxin and dexamethasone on cerebral malaria in mice. Parasitology 1995, 111:443-454.

49. Deininger $M H$, Winkler $\mathrm{S}$, Kremsner $\mathrm{PG}$, Meyermann $\mathrm{R}$, Schluesener $\mathrm{HJ}$ : Angiogenic proteins in brains of patients who died with cerebral malaria. J Neuroimmunol 2003, 142:101-111.

50. Sachanonta N, Medana IM, Roberts R, Jones M, Day NP, White NJ, Ferguson DJ, Turner GD, Pongponratn E: Host vascular endothelial growth factor is trophic for Plasmodium falciparum-infected red blood cells. Asian Pac J Allergy Immunol 2008, 26:37-45.

51. D'Alessandro S, Gelati M, Basilico N, Parati EA, Haynes RK, Taramelli D: Differential effects on angiogenesis of two antimalarial compounds, dihydroartemisinin and artemisone: implications for embryotoxicity. Toxicology 2007, 241:66-74.

52. Lee J Zhou HJ, Wu XH: Dihydroartemisinin downregulates vascular endothelial growth factor expression and induces apoptosis in chronic myeloid leukemia K562 cells. Cancer Chemother Pharmacol 2006 57:213-220.

53. Pamplona A, Ferreira A, Balla J, Jeney V, Balla G, Epiphanio S, Chora A, Rodrigues CD, Gregoire IP, Cunha-Rodrigues M, Portugal S, Soares MP, Mota MM: Heme oxygenase- 1 and carbon monoxide suppress the pathogenesis of experimental cerebral malaria. Nat Med 2007, 13:704-710.

54. Touitou E, Waknine JH, Godin B, Golenser J: Treatment of malaria in a mouse model by intranasal drug administration. Int J Parasitol 2006, 36:1493-1498.

55. Ma N, Hunt NH, Madigan MC, Chan-Ling T: Correlation between enhanced vascular permeability, up-regulation of cellular adhesion molecules and monocyte adhesion to the endothelium in the retina during the development of fatal murine cerebral malaria. Am J Pathol 2006, 149:1745-1762.

56. Neill AL, Hunt NH: Pathology of fatal and resolving Plasmodium berghei cerebral malaria in mice. Parasitology 1992, 105:165-175.

57. Curfs $\mathrm{JH}$, Hermsen CC, Meuwissen JH, Eling WM: Immunization against cerebral pathology in Plasmodium berghei-infected mice. Parasitology 1992, 105:7-14.

58. Curfs $\mathrm{JH}$, van der Meide PH, Billiau A, Meuwissen JH, Eling WM: Plasmodium berghei: recombinant interferon-gamma and the development of parasitemia and cerebral lesions in malaria-infected mice. Exp Parasitol 1993, 77:212-223.

59. Engwerda C, Belnoue E, Grüner AC, Rénia L: Experimental models of cerebral malaria. Curr Top Microbiol Immunol 2005, 297:103-143.

60. Nagelschmitz J, Voith B, Wensing G, Roemer A, Fugmann B, Haynes RK, Kotecka BM, Rieckmann KH, Edstein MD: First assessment in humans of the safety, tolerability, pharmacokinetics, and ex vivo pharmacodynamic antimalarial activity of the new artemisinin derivative artemisone. Antimicrob Agents Chemother 2008, 52:3085-3091.

61. Rosenthal PJ: Artesunate for the treatment of severe falciparum malaria. N Engl J Med 2008, 358:1829-1836.

62. Gautam A, Ahmed T, Batra V, Paliwal J: Pharmacokinetics and pharmacodynamics of endoperoxide antimalarials. Curr Drug Metab 2009, 10:289-306.

63. Martins YC, Smith MJ, Pelajo-Machado M, Werneck GL, Lenzi HL, DanielRibeiro CT, Carvalho LJ: Characterization of cerebral malaria in the outbred Swiss Webster mouse infected by Plasmodium berghei ANKA. Int J Exp Pathol 2009, 90:119-130.

64. Xiao L, Patterson PS, Yang C, Lal AA: Role of eicosanoids in the pathogenesis of murine cerebral malaria. Am J Trop Med Hyg 1999, 60:668-73.

65. Mayor A, Serra-Casas E, Bardají A, Sanz S, Puyol L, Cisteró P, Sigauque B, Mandomando I, Aponte JJ, Alonso PL, Menéndez C: Sub-microscopic infections and long-term recrudescence of Plasmodium falciparum in Mozambican pregnant women. Malar J 2009, 8:9.

66. Vivas L, Rattray L, Stewart LB, Robinson BL, Fugmann B, Haynes RK, Peters W, Croft SL: Antimalarial efficacy and drug interactions of the novel semi-synthetic endoperoxide artemisone in vitro and in vivo. $J$ Antimicrob Chemother 2007, 59:658-665.

\section{doi:10.1186/1475-2875-9-227}

Cite this article as: Waknine-Grinberg et al:: Artemisone effective against murine cerebral malaria. Malaria Journal 2010 9:227.

\section{Submit your next manuscript to BioMed Central and take full advantage of:}

- Convenient online submission

- Thorough peer review

- No space constraints or color figure charges

- Immediate publication on acceptance

- Inclusion in PubMed, CAS, Scopus and Google Scholar

- Research which is freely available for redistribution 